\title{
The Role of Trans-Disciplinary Research in Sustainable Renovation
}

\author{
Kristina Mjörnell ${ }^{1 \& 2}$ \\ ${ }^{1}$ RISE Research Institutes of Sweden, 41258 Gothenburg, Sweden \\ ${ }^{2}$ Division of Building Physics, Lund University, 22100 Lund, Sweden \\ Correspondence: Kristina Mjörnell, RISE Research Institutes of Sweden, 41258 Gothenburg, Sweden. E-mail: \\ kristina.mjornell@ri.se
}

Received: November 8, 2019 Accepted: November 27, 2019 Online Published: December 13, 2019

doi:10.5539/jms.v10n1p1 URL: https://doi.org/10.5539/jms.v10n1p1

\begin{abstract}
The paper discusses the role of trans-disciplinary research networks tackling the challenges of sustainable renovation such as; environmental impact of substitute building materials and waste, relocation of tenants, lack of skilled labor, rent increase due to high renovation costs, and provides a detailed perspective on the effects in terms of both new forms of collaboration and research results obtained by the researchers and practitioners within the network. The research network Sustainable Integrated Renovation SIRen has become a platform for researchers and actors such as building owners, housing companies, facility managers, contractors, consultants, architects, building conservationists, authorities and tenants' organisations to meet and work together on technical, environmental, economic, social and cultural historical aspects on renovation of buildings, as well as to identify and discuss new challenges. A multi-aspect process covering all aspects that must be considered by the various actors during different stages of the renovation process has been developed and implemented in four 'Living Labs' in real renovation projects. This involved using new modes of work in early stages to place the focus on sustainability aspects and work on new dialogue methods and using methods to evaluate the various renovation options based on technical, environmental, economic, social and cultural historical perspectives.
\end{abstract}

Keywords: sustainable renovation, trans-disciplinary research environment, collaboration arena, multi-aspect framework

\section{Introduction}

\subsection{Background}

Sweden, like many other nations in Europe, faces a need for large-scale, urgent renovation of post-war building stock that is past its technical, economic, and service life endpoint (Boverket, 2015). Neither the government nor the building sector is prepared for these challenges, however, as there is a lack of policy regarding dealing with housing shortages and affordability, and regulations are simultaneously pushing for reduced energy usage (Mangold et al., 2016). In the last ten years there has been a major focus on energy-efficient renovation (Atkinson et al., 2009; De Boek et al., 2015; Högberg et al., 2009). However, the renovation strategies of housing companies have changed, from extensive renovation to step-by-step renovation with a focus on societal issues (Femenias, Mjörnell, \& Thuvander, 2018). The EU Directive on the Energy Performance of Buildings (EPBD) contains measures for reducing the EU's energy dependency and greenhouse gas emissions (European Parliament and Council, 2010), and the Energy Roadmap 2050 explores the challenges posed by delivering on the EU's decarbonisation objectives while simultaneously ensuring the security and competitiveness of energy supplies (European Comission, 2012). Buildings are responsible for $40 \%$ of energy consumption and $36 \%$ of $\mathrm{CO}_{2}$ emissions in the EU, and it is predicted that $50 \%$ of the building stock that will exist in 2050 have been built before 1975 (BPIE, 2011). Therefore, the renovation of existing buildings has the potential to lead to significant energy savings, potentially reducing the EU's total energy use by $5-6 \%$ and lowering $\mathrm{CO} 22_{2}$ emissions by approximately 5\% (BPIE, 2011; Kamari et al., 2017). In the building sector, knowledge of renovation is highly fragmented and difficult to access for professionals, and the production of new buildings is normative regarding innovations in materials, techniques, regulations, information, education, and training. The pragmatic reality of the market, political visions and objectives, municipal and private services, and the needs of inhabitants and citizens must all be reconciled in order to create socially, environmentally, and economically sustainable built environments. 
Achieving the goal of sustainability requires understanding of and management of interconnected challenges and therefore a trans-disciplinary approach is a key component in sustainable building research (Brandt et al., 2013). Trans-disciplinary approaches have been posited as a means of solving and mitigating the problems that arise when disciplinary and interdisciplinary research falls short. Working in a trans-disciplinary group which has the goal of presenting a joint model or method demands a willingness to understand the context that each researcher is acting within, and it takes time to transfer such experience and knowledge. The differences between fields of research must be bridged in the socio-technical sciences. One challenge is to understand which disciplines are needed in order to tackle specific research questions (Pedersen et al., 2018).

It is generally agreed that sustainability challenges require new methods of knowledge production and decision-making. One key aspect of sustainability science, therefore, is the involvement of actors from outside academia in the research process in order to integrate the best available knowledge, reconcile values and preferences, and create ownership of problems and solutions (Kamari et al., 2018). Trans-disciplinary, community-based, interactive, or participatory research approaches are often suggested as appropriate means of meeting both the requirements posed by real-world problems and the goals of sustainability science as a transformational scientific field (Lang et al., 2012).

In the context of building renovation, a short-term and reductionist view that favours cost-cutting and efficiency could lead to devastating and irrevocable losses of existing and functioning social values and architectural and cultural-historical qualities (Broström et al., 2014). There are also indications that uninformed architectural decisions lead to the replacement of existing, and often still functional, materials and building components with new ones that have shorter technical and aesthetic lifespans, resulting in increased material flows as well as the loss of architectural and historical values (Femenias \& Thuvander, 2015). From this perspective, renovation involves a complex decision-making process in which multiple requirements and conditions has to be taken into consideration simultaneously. Therefore, sustainable renovation requires a multi-disciplinary approach, involving experts from different fields of knowledge working alongside building owners, tenants, and practitioners to design, construct, and operate buildings (Tupenaite et al., 2010). The integration of heritage values into decision-making frameworks for energy efficiency has not progressed, partially due to a lack of collaboration between the professionals involved in such projects who possess theoretical and practical expertise in heritage-management methods and tools for understanding heritage values (Fouseki \& Cassar, 2014). Another important aspect that hampers effective renovations is the lack of adequate construction skills among mid-level and senior building professionals, as well as the various trade professionals in the area of sustainable energy-efficient construction. Improving these is therefore of key importance (BUILDUP, 2018).

There are a number of examples of research and innovation collaborations between academia, research institutes, and industry in the field of sustainable urban development. One is Milparena, a network project with the ambition of creating interaction and shared knowledge between actors who are engaged in energy-efficient renovation involving municipal housing companies, energy companies, researchers, and governmental organisations (Dalenbäck \& Mjörnell, 2011). Although the project was not characterised as having a community focus, it showed potential for facilitating learning and the sharing of knowledge. Social interaction relating to a specific interest facilitated learning among individuals of various backgrounds (Gluch et al., 2013). The creation of an arena through meetings, discussions, and reflections that can support social learning is seen as a core activity (Femenias, Mjörnell, \& Thuvander, 2018). It is a well-established fact, however, that joint knowledge production can suffer from confounded agendas, reluctance to face exposure, and varying value preferences (Wiek et al., 2012).

The challenge of maintaining industry commitment throughout a project was noted by Thune and Gulbrandsen (2014), who found that large companies (in particular) with somewhat vague ambitions often leave consortia before the end of the contract period. However, the study also identified a 'nice to have' motivation, which could explain why many companies continue in partnerships even though they are not very active and frequently change the personnel who participate in meetings. From an academic perspective this is seen as a negative with regards to the transfer of knowledge, learning, and the advancement of research agendas, but is positive from the point of view of companies in terms of spreading knowledge to more people. The motivation of the partners was to have access to ground-breaking knowledge and networks (Thune \& Gullbrandsen, 2014).

Academia and industry have different goals, cultures, and structures, and these differences can create a fruitful basis for innovation and accessing new knowledge. Villani et al. (2017) argues that the crucial pre-conditions for inter-organisational collaboration are; cognitive (ways of perceiving, interpreting, and understanding the world), geographical (spatial distance between workplaces), organisational (similarities in routines, regulations, and incentives), and social (personal relationships between actors involving trust and friendship) (Villani et al., 2017). 
The authors also point out that geography seems to be important when facilitating collaborations between academic and non-academic organisations but is less important for inter-academic collaboration (Villani et al., 2017).

Collaborative work that is connected to pilot projects has been shown to play an important role in facilitating knowledge sharing and learning across organisational and professional boundaries (Gluch et al., 2013). Inter-relationships between people arise from engagement in practice and not idealised perspectives. Heiskanen et al. (2010) stress that user involvement and co-design requires a degree of flexibility during project planning, but most governmental projects require detailed plans that cannot be changed easily. They suggest that, if funding bodies want their projects to make a real difference, they should allow for changes in project plans (Heiskanen et al., 2010).

Limited research has been performed regarding collaboration and industry-academia relationships in the field of construction (Bröchner \& Lagerqvist, 2016). Experience of working in a number of local trans-disciplinary research arenas for energy-efficient renovation, sustainable construction, and transparent underground structures in a Swedish context (usually involving only one or two academic partners) has been reported by a number of researchers (Dalenbäck \& Mjörnell, 2011; Gluch et al., 2013; Femenias \& Thuvander, 2018; Kadefors \& Olofsson, 2019). No detailed studies, however, have been conducted on the real outcomes of national trans-disciplinary research arenas involving several academic partners as well as authorities and public organisations, and non within the field of sustainable integrated renovation. The Sustainable Integrated Renovation, SIRen research environment (http://www.renoveringscentrum.lth.se/siren/) gathered scientists from engineering, architecture, social sciences, real-estate management institutions at universities, research institutes in Sweden and committed industrial and public actors to focus on renovation from environmental, economic, social, and cultural perspectives. SIRen is unique as it involves representatives from different disciplines at ten universities and institutes and more than thirty partners representing industry, authorities, and NGOs with a focus on different perspectives on sustainable renovation. Unlike many other collaborative projects, researchers and partners within SIRen have had a great freedom to initiate new project ideas during the course of the project as long as they are within the framework of the research environment.

The aim of this paper is to discuss the role of trans-disciplinary research networks including benefits and challenges of collaboration, regarding tackling the complex challenges of sustainable renovation. The paper provides a detailed perspective on the effects of this environment in terms of both the connections and research results (in terms of publications, Living Labs, and events) obtained by the researchers and practitioners within the network. It begins with a description of the method of evaluation, which is followed by a discussion of the quantitative and qualitative results, such as connections, collaborations, and research output, and then the results of the survey and results obtained within the research environment. The paper concludes with a discussion of the challenges and benefits of a trans-disciplinary research environment and its openness in terms of changing directions within the research field, and presents several suggestions and conclusions drawn from the work so far.

\subsection{Description of the Research Environment}

The SIRen research environment was established in 2014, and gathered together scientists from engineering, architecture, social sciences and the real-estate management personnel from a number of academic institutions and institutes in Sweden and committed industrial and public actors, see Appendix A. SIRen focuses on the complexities of the renovation of existing buildings and redevelopment of urban areas, along with the issues involved in conforming to objectives for reducing climate change, altered demographics, and democracy in planning. These are among the most important challenges to contemporary society that must be handled within the economic context of construction and without the aid of national subsidies. The approach is inter-disciplinary research, which in practice means that it takes some elements from different disciplines, but with a solid basis in disciplinary research. Contemporary practices that fail to integrate societal objectives within environmental protection have been challenged, and the aim has been to produce research that supports the sector's ability to deliver increasing sustainability. The research aims to gather existing knowledge and build new in order to make renovation methods and processes more sustainable, thus strengthening Swedish competitiveness for renovation in terms of both practice and research and development, both nationally and internationally. The goal is for the models and methods for integrated sustainable renovation that are being developed, to be widely used in the industry in the future, and for this to strengthen the competitiveness of the Swedish building sector. 


\subsubsection{Approach and Activities}

The approach is to integrate technical, environmental, economic, architectural, and cultural issues in renovation, taking the social dimension as its starting point and focusing on multi-value approaches and multi-stakeholder involvement. Within SIRen, knowledge is gathered and methods for sustainable and integrated renovation are developed and implemented, with the aim of changing national renovation practice and strengthening the international competitiveness of Swedish renovation practice and research. This is realised through the following activities:

- Establishing a knowledge base

- Documenting and analysing previous and on-going renovation work

- Testing and accelerating the diffusion of innovation through demonstrations and Living Labs

- Developing models, methods, and tools for integrated and sustainable renovation

- Communicating, engaging in dialogue regarding, and disseminating results

\subsubsection{Living Labs}

Four Living Labs, in which new methods and tools were implemented in the renovation process and stakeholders were involved in an effort to make it more sustainable and integrated, were established and have been studied. The Living Labs are located in Hammarkullen and at Siriusgatan in Gothenburg, at the Ulriksberg School in Växjö, and in the Tjärna Ängar residential area in Borlänge (all in Sweden).

\subsubsection{Forms of Collaboration}

Since the daily work is carried out in separate projects at several universities is was essential to have regular meetings. Therefore, two-days meetings have been arranged twice a year with the aim to discuss the work performed in the various areas and next steps, as well as new specialisations that could form the basis for spin-off projects from SIRen. The choice of location and responsibility for arranging the meetings has alternated among the participating organisations, giving the host organization an opportunity to raise specific topics of interest and arrange study visits to local projects of special interest, such as the Living Labs. Between these meetings, several thematical workshops and seminars with focus on the renovation strategies of building owners have been arranged.

Several personnel have quit their positions and been replaced during the duration of the project, which has been a challenge when it comes to knowledge transition and team building. Therefore, every meeting has started with a session where every participant, approximately 40-50 persons each time, had a few minutes to inform the rest of the group about their main activities and achievements since the last meeting. A short introduction to the SIRen research environment was made, both to freshen up existing participants and make it easier for new participants to understand the context and to get to know the partners in the project. In the end of each meeting there was also time for feedback and suggestions for the format and thematic orientation of the next meeting, which gave the opportunity for everyone to be involved in the planning of the themes for discussions and research focus.

Approximately ten PhD students who have been actively involved in SIRen have formed a network for the next generation of building-renovation researchers. This resulted in a number of close collaborations based strongly on relationships and even friendships between the $\mathrm{PhD}$ students, which has led to a number of co-authored publications. Ethical guidelines were discussed among the researchers and ethical codes of conduct agreed upon early in the process to avoid conflicts of interests between researchers, considering for example publication of scientific results.

Gradually, based on the results of ongoing research as well as events in the outside world, new ideas have been brought forward within the research environment. Many new initiatives have led to collaborations between researchers who have never worked together before, and their applying for funding in order to approach topics in a trans-disciplinary manner. This is a good example of how a research environment creates noticeable ripples on the water and generates more funding for the research area than would be the case without the collaboration. The spin-off projects include studies of social indicators for contractors, following up on sustainable renovation in real renovation cases, relocation patterns among tenants, the environmental impact of internal renovation and material flows, heat recovery from wastewater from buildings, stepwise renovation and the araising problems with overcrowding in some residential areas, as a few examples. 


\section{Methods}

In order to evaluate the impact of the inter-disciplinary research environment on research output, such as increased knowledge, development of and experience from implementation of new methods and processes, concerning sustainable integrated renovation, quantitative methods have been used to collect and compile the achieved results. In order to gather this information, the partners involved in the research environment have reported their achieved results, which take the form of published material, academic merits, new research projects, dissemination activities, etc. on an annual basis. These reports have also included an account of the extent to which they participated in the various work packages, how many events and workshops they have participated in, the number of publications, the number of $\mathrm{PhD}$ students involved and their degrees, how many doctoral courses and information and communications activities they have held. They have also reported the number of new projects applied for and granted that originated within the research environment, along with mention of any other related projects in progress and public outreach. The submission of reports of quantitative results is incentivised by the fact that funding can only be obtained after results are reported.

Qualitative methods were used to gather feedback from the actors participating in the research environment. The collection of information was performed by sending a digital survey to all of the participants in the SIRen network, which posed a number of questions regarding new research opportunities, the network, and the forms of collaboration. The survey was distributed via email to a mailing list of people who were active in the research environment at some point during the project period, which was approximately 120 persons. A reminder was sent a week after the first email, and the survey was closed after two weeks. The participants were asked to respond to a number of statements and questions, see Appendix B.

\section{Results}

\subsection{Quantitative Results}

Research within the SIRen research environment focuses on complex issues relating to everything from the renovation of individual buildings to upgrading entire areas. These include how the industry should handle societal challenges such as climate change, changing demographics, and increased segregation while contributing with an increased influence on renovation processes, and how this should be accommodated within the financial frameworks of real estate companies. Within the research environment, the technical, environmental, economic, architectural, and cultural historical aspects of renovation were integrated based on the social dimension. Methods and processes that consider all sustainability aspects, which are based on participation and commitment from many actors and stakeholders, have been developed. The SIRen research environment is based on interdisciplinary collaboration between researchers at universities, colleges, and institutes, actors in the construction and real-estate industries, and relevant authorities. Examples of the results achieved are described in the following sections.

\subsubsection{Knowledge Hub}

The results of research have been gathered, evaluated, and categorised through the mapping of on-going and recently finished research projects conducted by SIRen members and other actors and published in a research paper (Abdul Hamid et al., 2018). In order to make the obtained knowledge easy to access, short summaries have been written and placed on the national website www.ichb.se, along with links to further documentation. The research concerns topics such as energy renovation measures, case studies, quality assurance methods, measurements in buildings, energy simulations etc. In addition, a visualization of the existing building stock in Sweden showing future renovation needs, energy-saving potential, and average resident incomes have been produced based on statistics and international databases and compiled in an 'energy atlas' (Johansson et al., 2017). This has been used to shape national renovation strategies and frame subsidies for socio-economically vulnerable areas, among other things.

\subsubsection{Evaluation of Performed Renovations}

A review of completed renovation projects has been carried out; this used the quality of data as a basis for decisions regarding projects and found that there is often a lack of quality-assured information at all stages, which affects the decisions made and thus the result of a renovation (Femenias, Gluch, \& Mjörnell, 2018; Farsäter \& Olander, 2019; Farsäter et al., 2019).

\subsubsection{Living Labs}

In order to test and evaluate new technologies and models for financing, dialogue, and management alongside companies, four Living Labs were established in Hammarkullen, Siriusgatan, Ulriksberg school and Tjärna Ängar, Figure 1. 
The general research question in Hammarkullen was how sustainable management can affect future renovation needs. The purpose of the project is to develop knowledge regarding what tenants, property owners, and property managers consider to be important in relation to management and refurbishment, as well as to build confidence in the continued relationship with tenants and change the balance of power for tenants in ongoing and already-initiated processes and results were published in (Stenberg \& Fryk, 2015).

The overall objective of renovation of Siriusgatan is to achieve sustainable renovation through increased collaboration in the early stages of processes. The question was if such cooperation could contribute to the creation of a new decision-making model or framework for urban renewal and renovation? As part of this, Gothenburg Municipality will establish a partnership between the public housing company Familjebostäder and the Municipality's planning, property and technical administrations in order to plan and implement a renewal of Siriusgatan in Bergsjön, which includes both renovation and new construction. Familjebostäder, in cooperation with researchers from SIRen, has developed an inventory prior to renovation and implemented a dialogue method with the residents in the preliminary study. The work has been followed and reported by researchers from SIRen (Femenias, Gluch, \& Mjörnell, 2018).

The municipal building owner VÖFAB assessed the various possible options for the Ulriksberg School that is in urgent need of reconstruction, considering both demolition and different degrees of renovation. SIRen researchers followed, documented, and evaluated the decision-making process. Regular meetings were held between SIRen participants and representatives of VÖFAB and Växjö Municipality's space planning group, and study visits were made to the school to learn more about the conditions in reality. The results were published in (Farsäter \& Olander, 2019).
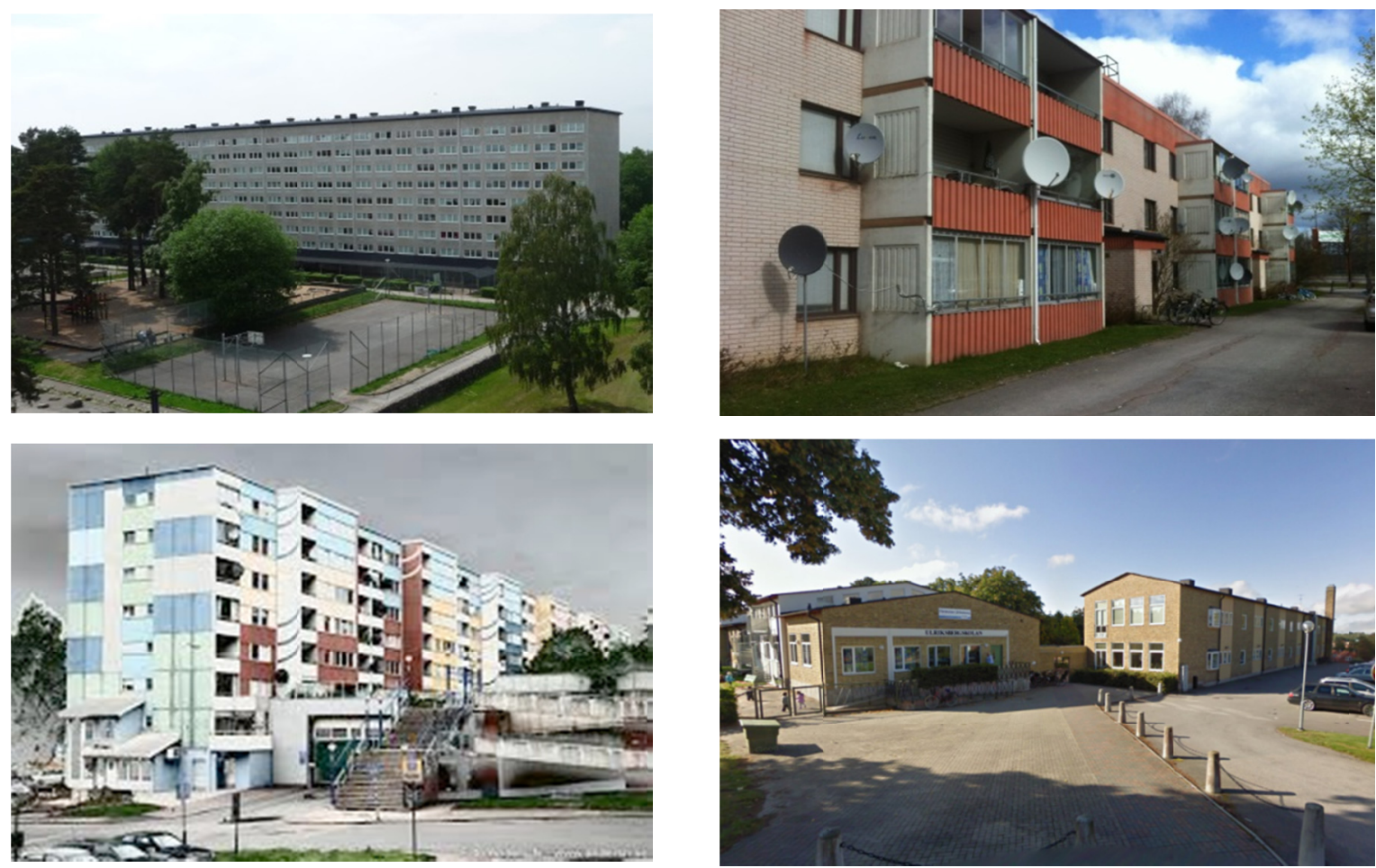

Figure 1. The four SIRen Living Labs: Top-left: Hammarkullen, Gothenburg. Top-right: Tjärna ängar, Borlänge. Bottom-left: Siriusgatan, Gothenburg. Bottom-right: The Ulriksberg School, Växjö

Researchers are working with the housing company Tunabyggen in Borlänge on an existing rental house in the residential area of Tjärna Ängar. They have fully explored how combined heat- and power-extraction systems and exhaust ventilation (FX) systems can technically, financially, functionally, and ergonomically meet the requirements of NZEB (nearly zero energy) buildings. The tenants' comfort, participation, and sense of democratic engagement as regards decision-making processes have also been analysed. This is a pre-requisite for avoiding costly evacuations and optimising the process of sustainable renovation. The ability of the actors to make optimal decisions at the right times during the decision-making process in order to ensure a cost-effective 
sustainable renovation has been studied. Based on the results, a model for Tunabyggen's continued renovation, along with similar residential buildings, have been created, which could function as a useful example within the national research environment (Lidberg et al., 2017).

\subsubsection{A Process for Sustainable Integrated Renovation}

A comprehensive process for sustainable renovation with a holistic approach to renovation has been developed, taking into consideration the areas of technology, the environment, the economy, social values, architecture, and the cultural historical environment. The so-called SIRen process describes activities that will be carried out at different stages of the process and assigns responsibility for these activities, Figure 2. The SIRen process refers to available methods, tools, and procedures that can be used for inventories, analyses, and decisions in the different stages of the renovation process in order to include all of the aspects that are essential to achieving sustainable refurbishment. After each stage (planning, design, reconstruction, and commission) of the renovation process, a self-evaluation can be made so as to estimate to what extent each sustainability aspect has been considered and included.

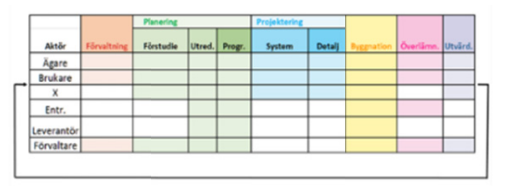

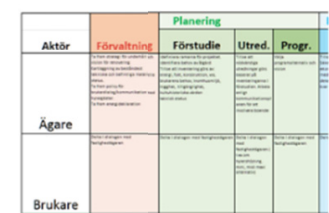

Overview

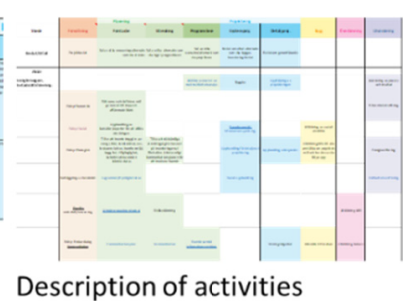

Description of activities

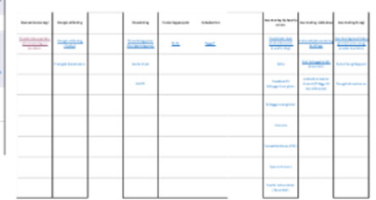

Links to tools and documents

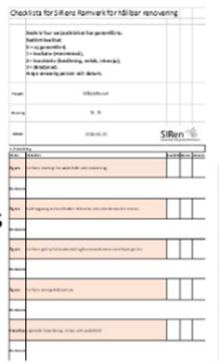

Check-list

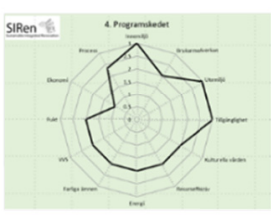

Self-evaluation

Figure 2. Schematic picture of the SIRen process with layers of accessible information and tools

\subsubsection{Dissemination Activities}

A number of dissemination activities have been carried out to date: Publishing of 2 anthologies, 10 summary reports, more than 40 scientific papers in journals and 50 conference papers, 12 reports, $6 \mathrm{PhD}$ theses, 57 Master theses and a number of popular science articles, and more will come. The participants have also held presentations at conferences, seminars, and public events, and have had dialogues with politicians, authorities, and professional organizations, as well as arranging student projects, and a $\mathrm{PhD}$ course. More detailed information can be found at http://www.renoveringscentrum.lth.se/siren/.

Trans-disciplinary collaboration was practiced when the group agreed to publish an anthology on the topic of socially sustainable renovation, consisting of chapters on different aspects of renovation from a social point of view authored by both researchers and professionals (Lind \& Mjörnell, 2015). As a summary of results from the research environment an anthology on sustainable integrated renovation was published, consisting of chapters co-authored by at least two people from different disciplines, such as real-estate economics, building technology, architecture, social science, cultural history, energy efficiency, and data analytics, or of different academic affiliations (Olander et al., 2019).

\subsection{Qualitative Results}

The qualitative feedback from the actors was collected by sending a digital survey to all of the participants in the SIRen network, in which a number of questions were asked about new research opportunities, the network, and forms of collaboration. In total, 34 responses were received regarding the experience of being part of the research environment. This was considered as a reasonably high number of respondents since only about 40-50 persons are active in the SIRen research environment on a long-term basis. 


\subsubsection{Multiple Choice Questions}

A selection of the results is shown in the following (Figures 3-5).

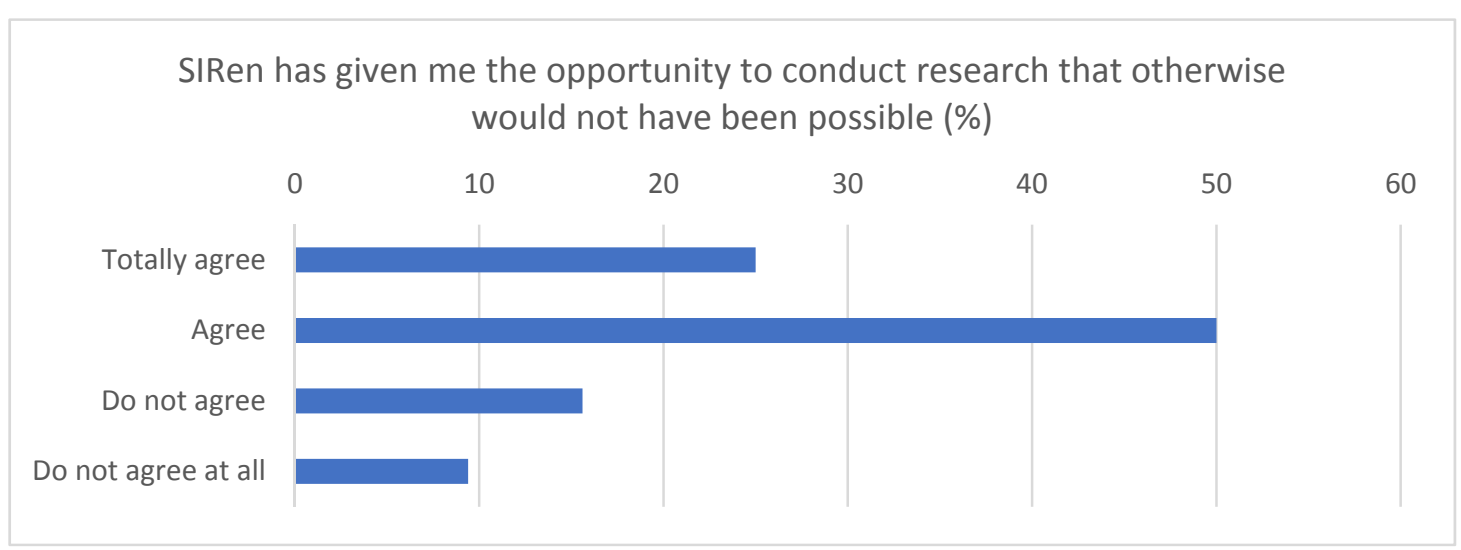

Figure 3. Results for Question 1. SIRen has given me the opportunity to conduct research that otherwise would not have been possible

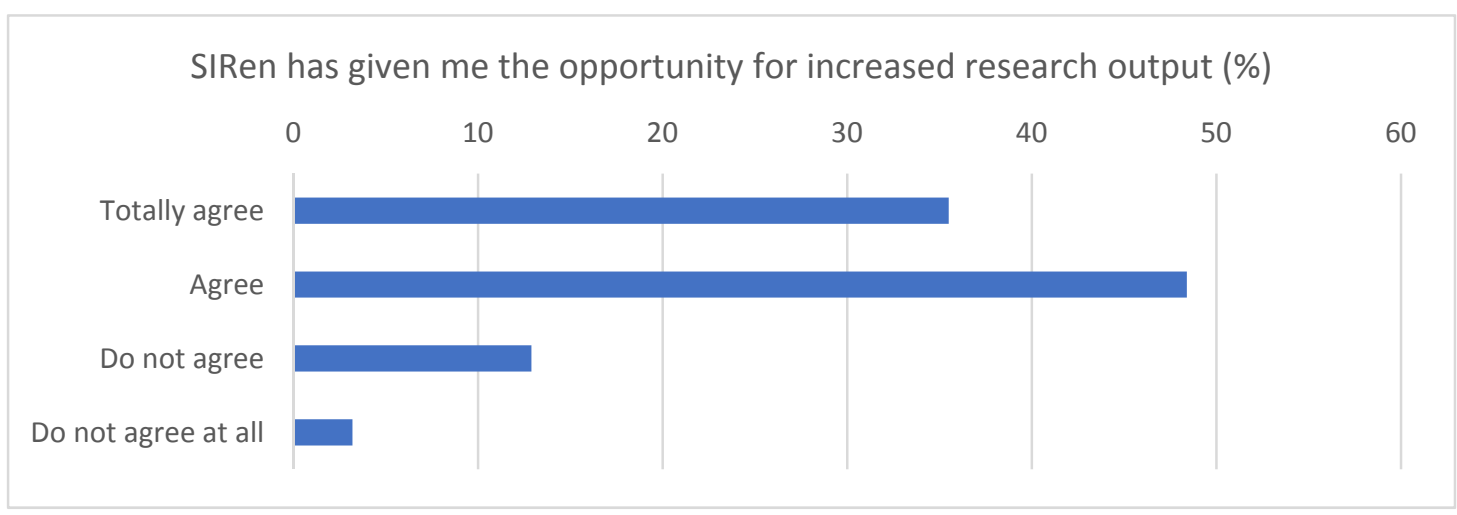

Figure 4. Results for Question 3. SIRen has given me the opportunity for increased research output

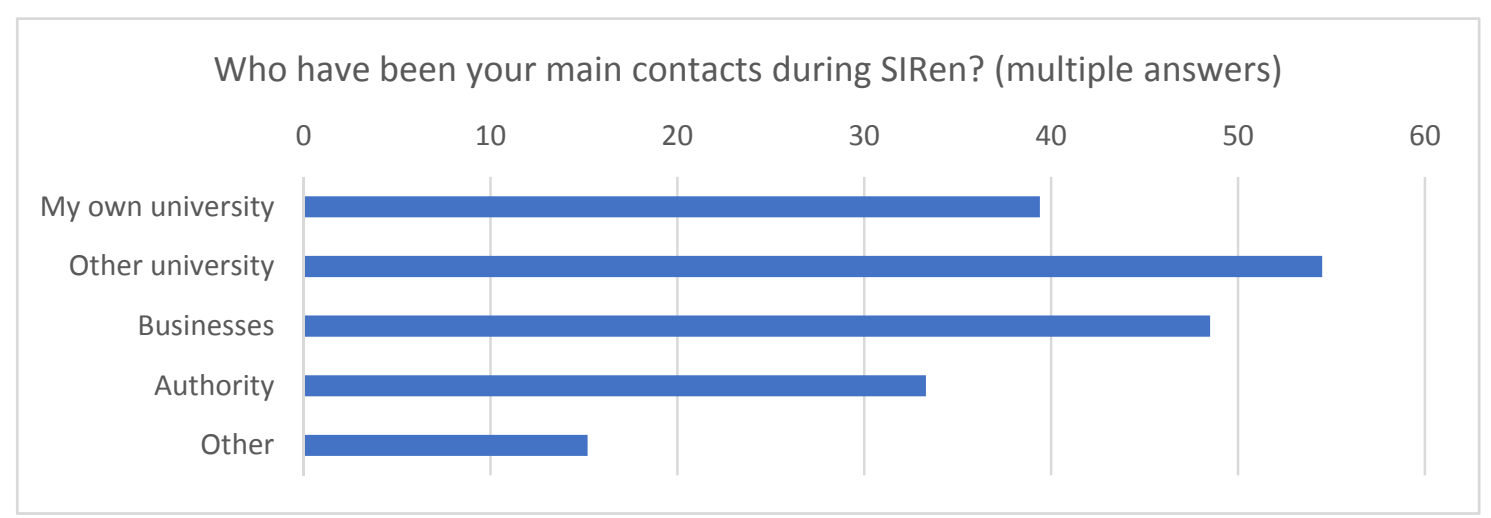

Figure 5. Results for Question 12: What have been your main contacts during SIRen? Public sector and non-profit organisations are examples of the groups listed for the 'other' category

\subsubsection{Open-Ended Answers}

Two of the questions in the questionnaire allowed the respondents to answer in their own words: The results for the first, 'In what ways has SIRen benefited your research work?', suggest that SIRen has created a functioning 
arena for cooperation and co-production. Out of the 34 respondents, there were 21 free texts answers and 11 respondents mentioned the access to a large network of researchers and practitioners with regards to quickly posing questions, as well as developing long-term relationships and collaborations that will continue or develop further even after the project has ended. A few mentioned that SIRen is part of their development as professionals, and one respondent stated that it gave them the opportunity to return to a previous place of employment to perform research there and one have financed a $\mathrm{PhD}$ student. A representative of a public authority stated that SIRen has supported their work, and that they hoped to be able to contribute in return. With regards to communication, the general exchange of experience during meetings, conferences, and workshops was mentioned, as was the fact that SIRen has given the participants' research a national platform throughout academia and industry.

The second question was 'In what ways has SIRen developed your network?' Out of the 34 respondents, there were 19 free texts answers and 18 of these mentioned increased contacts, opportunities for meetings and networking and getting to know new people as a positive outcome of SIRen. Six respondents specifically stressed the importance of representatives from all of the stages of the construction process being included, from building owners and major contractors to individual consultants and from national authorities to representatives from municipalities. It was felt that the opportunity to communicate with people whom they otherwise would not have met was fruitful, and that the network offered time and space for discussion. Three respondents also mentioned the advantage of involving public authorities such as the Swedish National Board of Housing, Building and Planning, the Swedish National Heritage Board, and the Museum of Gothenburg, as this allowed new contacts to be made. Eleven respondents representing the researchers have mentioned the relationships with other researchers as well as industry and building owners, opening opportunities for joint applications, and researchers in the field of cultural historical buildings, for example, have obtained a much larger arena for their research. Integrating existing buildings into broader contexts is of the utmost importance for achieving success in both research and research communication, which will hopefully also be useful among non-researchers.

\section{Discussion}

\subsection{Challenges to Trans-Disciplinary Collaboration}

The difference between conducting research in a research environment and doing so within individual projects is that both the application and conducting of a research project within an area that is familiar to the researcher(s) are quite straightforward, whereas a collaborative project is very demanding with regard to common goals, the division of work, choice of methods, terminology, presentation of results, etc. In contrast to the underground infrastructure project TRUST (Kadefors \& Olofsson, 2018), many of those involved in SIRen did not know one another or even come from the same discipline from the start. The initial application involved approximately 30 senior researchers from different disciplines at ten universities and institutes. The partners from industry and the public sector who were invited to join the application were chosen primarily from the researchers' networks. Some of the organisations that signed up for the initial application dropped out when the contracts were to be signed, but at that time the research environment opened up for new organisations to sign up. The research environment has been kept open to new organisations who wanted to join throughout the duration of the project.

Villani et al. (2017) states that inter-organisational collaborations must meet four important pre-conditions: cognitive, geographical, organisational, and social (Villani et al., 2017). Geography seems to be important when facilitating collaboration between academic and non-academic organisations but is less crucial for inter-academic collaboration (Villani et al., 2017), as was clear with the collaborations that were formed within the SIRen research environment. The university partners have initiated research projects together with local housing companies and consultants in the same regions as the universities, which is more practical with regard to physical meetings and when the research involves carrying out inventories of buildings and interacting with tenants. One node exists in the west of Sweden (Chalmers, RISE, and Framtiden AB), one is in the south of Sweden (Lund University and Växjö Municipality), and one is in the middle of Sweden (Dalarna University and Tunabyggen). Collaborations between academic partners and authorities have occurred irrespective of location (Chalmers, RISE, Luleå University of Technology, and the Swedish National Board of Housing, Building and Planning; Lund University and Gotland University; RISE and KTH Royal Institute of Technology). Collaborations between researchers from different universities have primarily involved compiling data from different studies and co-authoring papers, both of which can be undertaken from a distance.

The importance of social pre-conditions for collaboration is obvious and has been supported by arranging the biannual conferences. These facilitated partners remaining informed of developments in the research environment, the discussing of contemporary issues and new topics of interest, inspiration from the presentation 
of work, a better understanding of the conditions and challenges for housing companies, and the development of friendships through meeting within a casual environment. A number of such relationships is the fruit of the collaborations within the research environment.

One challenge for researchers is agreeing on guidelines for collaboration. Pedersen et al. (2018) stress the importance of understanding the ethical issues in human subject research, as well as collecting and handling data that is to be published (Pedersen et al., 2018). Therefore, ethical guidelines for the sharing of data and publication were discussed and agreed upon early in the project.

Maintaining the interest of companies has been difficult, as was also found in an earlier study by Thune and Gulbrandsen (2018). Some companies were very active from the beginning, but their interest lapsed due to key personnel leaving and not being replaced, for example. In the SIRen research environment, the major contractors and materials and product manufacturers were active in the beginning, while smaller companies, public authorities, and the Swedish Union of Tenants, have shown more interest and actively participated in meetings, discussions, practical implementation and authoring publications in the long run.

\subsection{Benefits of Trans-Disciplinary Collaboration}

For the individual researcher, collaboration means expanding one's field of competence and gaining insight into new areas and practices, which can greatly benefit one's own research. It gives the researcher opportunities to meet compatriots at other research institutions and disciplines, as well as those in the business community. Moreover, collaboration facilitates the identification of societal and business challenges, and the conducting and application of new research that benefits society.

The benefits of SIRen for the industry include taking part in the network and making contact with prospective clients, as well as increasing their knowledge and learning. The research environment has been kept open and welcomed new partners throughout the course of the project. This has led to several organisations and companies that were not attached to the environment at the outset joining. Some organisations and companies that were not known to the research network prior to the project received information regarding it and thus were represented at a seminar. Modexa, a company that renovates kitchens with the ambition of preserving cabinets, recently joined the network, as did House of Hemp, which works with systems based on hemp bales for the renovation and insulation of traditional pit floors.

The Swedish Union of Tenants, which represents tenants and negotiates with housing companies regarding rent increases for renovation, has represented end users during the project and so provided new perspectives and balanced the interests of the housing companies. It has also been productive for housing companies to have more extensive contact with the Swedish Union of Tenants and obtain an improved understanding of how they work, which will hopefully result in increased cooperation in the future.

\subsection{Benefits of Relaxed Frameworks}

As Heiskanen (2010) states, research and innovation projects involving users and co-design require a degree of flexibility in project planning (Heiskanen et al., 2010). In contrast to most governmental projects, which require detailed plans that cannot be changed easily, the SIRen research environment is quite flexible as regards the selection of sites for the Living Labs and specific research topics, provided they are within the framework of the application. When the research environment was established, the focus was primarily on technical solutions for achieving a high degree of energy efficiency in existing buildings. However, the focus soon changed to economic and social issues when it became clear that a prerequisite for renovation is that renovation must be carried out without increasing rent by more than those living in the building can afford. The advantage of working long-term with a fairly high degree of freedom is that we have been able to answer questions that have been raised by the partners representing practices, users, and authorities as and when answers became available. One such question is whether increases in rent due to renovation work force people with low incomes to move, which was initially asked by one of the larger public housing companies. This gave the researchers the opportunity to apply for a project to study relocation patterns of tenants as a result of renovation.

Renovation practices as such has changed in terms of focus; from total renovation to more gentle renovation, with the aim of preserving as much of the materials and systems that are still in good condition as is possible. Within the SIRen research environment, we have organised workshops to discuss the circular economy in relation to refurbishment, exploring whether it is possible to reuse and recycle a larger proportion of materials and products and create a market for this.

As a result of the extensive immigration in Sweden in 2016, overcrowding is a problem in many residental areas. When $8-10$ people share an apartment that was designed for $2-3$, this may affect the indoor air quality and 
moisture conditions in the apartment. This topic has been brought up within the research environment, and a new research project has been initiated.

\section{Conclusions}

This paper discusses benefits and challenges of collaboration within a trans-disciplinary research environment with regard to tackling the complex challenges of sustainable renovation, and provides a detailed perspective on the effects of this environment in terms of both the connections and research results (in terms of publications, Living Labs, and events) obtained by the researchers and practitioners within the network.

The SIRen research environment has been bridging the gap between theory and practice in the field of building renovation research by gathering academia, industry, public authorities as well as representatives for tenants providing the opportunity of being part of a research network and coming into contact with prospective research partners, clients, and stakeholders, forming the basis for collaboration. The benefits of working in the inter-disciplinary research environment is that the participants have received a better understanding of the complex context of renovation and the importance of the investigations, analyses, and decisions made by different actors, among a number of researchers, companies, and authorities.

A network of researchers and practitioners from different disciplines has been created and close relationships have been built, both between researchers from different disciplines and practitioners and academic partners, particularly as regards local connections. This has led to a number of projects being initiated by small groups of actors, who have elaborated on new research ideas and applied for research funding together. Thus, the original funding allocated to the research environment has resulted in a number of spin-off projects, attracting multiple amounts compared to the original funding to the research area of sustainable renovation. It proofs the strength and value creation of investing in building strong research environments. Collaboration within the research environment has led to new knowledge and ideas that likely would not have been created or incurred within individual projects. A majority of the researchers and partners have expressed that being a part of the research environment has given them the opportunity to conduct research that would otherwise not have been done and also increased their research output, which is profitable for the building research community as a whole.

The four Living Labs have helped researchers to obtain a better understanding of the complex realities faced by housing companies/building owners and tenants/building users.

The housing companies, contractors, consultants, authorities and residents have obtained deeper insights into the different aspects of sustainable renovation and been provided with a framework of specific methods for implementing sustainability aspects in both strategic work and real renovation projects.

The challenges are to be productive working together and find efficient ways for collaboration with a limited budget and individual interests and limited time. The intention is to keep the network alive even after the funding has ended by continuing to hold biannual conferences, enabling participants to meet, exchange knowledge, and create ideas for cooperation. This is especially important for the young researchers who have not yet created large networks of contacts within the research environment. It will also ensure that knowledge is not tied to a particular research group or person, facilitating a changing of the generational guard. The network of young researchers initiated within the research environment will result in a solid platform for future collaboration and ensure a lasting network of researchers and stakeholders.

\section{Acknowledgements}

The authors would like to thank The Swedish Research Council Formas for their financial support, which was used to establish the SIRen research environment. Stefan Olander and Paula Femenias are acknowledged for helping to formulate the questionnaire, and Stefan for helping to administer the digital survey.

\section{References}

Abdul, H. A., Farsäter, K., Wahlström, Å., \& Wallentén, P. (2018). Literature review on renovation of multifamily buildings in temperate climate conditions. Energy and Buildings, 172, 414-431. https://doi.org/10.1016/j.enbuild.2018.04.032

Atkinson, J. G. B., Jackson, T., \& Mullings-Smith, E. (2009). Market influence on the low carbon energy refurbishment of existing multi-residential buildings. Energy Policy, 37(7), 2582-2593. https://doi.org/10.1016/j.enpol.2009.02.025

Boverket. (2015). Förslag till utvecklad nationell strategi för energieffektiviserande renovering. Proposals for developed national strategy for energy efficient renovation, 2015. Boverket. ISBS pdf: 978-91-7563-334-3. Retrieved 
https://www.boverket.se/globalassets/publikationer/dokument/2015/forslag-till-utvecklad-nationell-strategifor-energieffektiviserande-renovering.pdf

BPIE. (2011). Europe's Buildings under the Microscope. Buildings Performance Institute Europe (BPIE): Brussels, Belgium.

Brandt, P., Ernst, A., Gralla, F., Luederitz, C., Lang, D., Newig, J., ..., von Wehrden, H. (2013). A review of transdisciplinary research in sustainability science. Ecological Economics, 92, 1-15. https://doi.org/10.1016/j.ecolecon.2013.04.008

Bröchner, J., \& Lagerqvist, O. (2016). From ideas to construction innovations: firms and universities $\begin{array}{lllll}\text { collaborating. Construction Economics and } & \text { Building, }\end{array}$ https://doi.org/10.5130/AJCEB.v16i1.4668

Broström, T., Eriksson, P., Liu, L., Rohdin, P., Ståhl, F., \& Moshfegh, B. (2014). A Method to Assess the Potential for and Consequences of Energy Retrofits in Swedish Historic Buildings. The Historic Environment: Policy \& Practice, 5(2), 150-166, https://doi.org/10.1179/1756750514Z.00000000055

BUILDUP Skills. (2018). Retrived November 7, 2017, from https://cordis.europa.eu/article/id/400910-new-skills-for-the-construction-sector-to-achieve-european-energ y-targets_en.html

Dalenbäck, J.-O., \& Mjörnell, K. (2011). Milparena-A Network Project Knowledge Enhancement Regarding Energy Renovation of Multi-family Buildings in Sweden. Ökosan 2011 in Graz, 2011.

De Boeck, L., Verbeke, S., Audenaert, A., \& De Mesmaeker, L., (2015). Improving the energy performance of residential buildings: a literature review. Renewable and Sustainable Energy Reviews, 52, 960-975. https://doi.org/10.1016/j.rser.2015.07.037

European Commission. (2012). Energy Roadmap 2050. COM (2011); European Commission: Brussels, Belgium, 2012; ISBN 9789279217982.

European Parliament and Council. (2010). Directive 2010/31/EU of the European Parliament and of the Council of 19 May 2010 on the energy performance of buildings (pp. 13-35). Off. J. Eur. Union 2010, L153.

Farsäter, K., \& Olander, S. (2019). Early decision-making for school building renovation. Facilities. https://doi.org/10.1108/F-10-2017-0102

Farsäter, K., Strandberg, P., \& Wahlström, Å. (2019). Building status obtained before renovation multifamily buildings in Sweden. Journal of Building Engineering, 24, July, 100723. https://doi.org/10.1016/j.jobe.2019.02.015

Femenias, P., Gluch, P., \& Mjörnell, K. (2018). Challenges for sustainable integrated renovation: experiences from a Swedish case of a large housing estate. Retrofit Europe! Nov 2018, Eindhoven, NL.

Femenías, P., Mjörnell, K., \& Thuvander, L. (2018). Rethinking deep renovation: The perspective of rental housing in Sweden. Journal of Cleaner Production, 195, 1457-1467. https://doi.org/10.1016/j.jclepro.2017.12.282

Femenías, P., \& Thuvander, L. (2015). The unspoken: Architectural values, material flows and renovation of modern housing stock. 31th International PLEA Conference, 9th-11th September, Bologna.

Femenias, P., \& Thuvander, L. (2018). Transdisciplinary Research in the Built Environment: A Question of Time. Technology Innovation Management Review, 8(8), 27-40. https://doi.org/10.22215/timreview/1176

Fouseki, K., \& Cassar, M. (2014). Energy Efficiency in Heritage Buildings-Future Challenges and Research Needs. The Historic Environment: Policy \& Practice, 5(2), 95-100, https://doi.org/10.1179/1756750514Z.00000000058

Gluch, P., Johansson, K., \& Räisänen, C. (2013). Knowledge sharing and learning across community boundaries in an arena for energy efficient building. Journal of Cleaner Production, 48, 232-240. https://doi.org/10.1016/j.jclepro.2012.10.020

Heiskanen, E., Feenstra, C. F. J., Johnson, M., \& Vadovics, E. (2010). Learning about users and developing co-design capabilities for energy saving on the local level. Knowledge Collaboration \& Learning for Sustainable Innovation. ERSCP-EMSU conference, Delft, The Netherlands, October 25-29.

Högberg, L., Lind, H., \& Grange, K. (2009). Incentives for improving energy efficiency when renovating large-scale housing estates: a case study of the Swedish million homes programme. Sustainability, 1(4), 
1349-1365. https://doi.org/10.3390/su1041349

Johansson, T., Olofsson, T., \& Mangold, M. (2017). Development of an energy atlas for renovation of the multifamily building stock in Sweden. Applied Energy, 203, 723-736. https://doi.org/10.1016/j.apenergy.2017.06.027

Kadefors, A., \& Olofsson, T. (2019). Collaborative innovation in infrastructure construction a sense-making perspective. Manuscript.

Kamari, A., Corrao, R., \& Kirkegaard, P. H. (2017). Sustainability focused Decision-making in Building Renovation. International Journal of Sustainable Built Environment, 6(2), 330-350. https://doi.org/10.1016/j.ijsbe.2017.05.001

Kamari, A., Carrao, R., \& Kirkegaard, P. H. (2018). A Holistic Multi-methodology for Sustainable Renovation. International Journal of Strategic Property Management, 23(1), 50-64. https://doi.org/10.3846/ijspm.2019.6375

Lang, D. J., Wiek, A., \& Bergmann, M. (2012). Transdisciplinary research in sustainability science: practice, $\begin{array}{lllll}\text { principles, and } & \text { Shallenges. }\end{array}$ https://doi.org/10.1007/s11625-011-0149-x

Lidberg, T., Gustafsson, M., Myhren, J., Olofsson, T., \& Trygg, L. (2017). Environmental impact of energy refurbishment of buildings within different district heating systems. Applied Energy, 227, 231-238. https://doi.org/10.1016/j.apenergy.2017.07.022

Lind, H., \& Mjörnell, K. (2015). Social hållbarhet med fokus på Bostadsrenovering - en antologi. SIRen report 2015:4. ISBN 978-91-88001-80-1.

Mangold, M., Österbring, M., Wallbaum, H., Thuvander, L., \& Femenias, P. (2016). Socio-economic impact of renovation and energy retrofitting of the Gothenburg building stock. Energy and Buildings, 123, 41-49. https://doi.org/10.1016/j.enbuild.2016.04.033

Olander, S., Mjörnell, K., Femenias, P., Helsing, E., \& Wallentén, P., Editors. (2019). Hållbar renovering ur ett helhetsperspektiv - En antologi från forskarmiljön SIRen. SIRen report 2019:2. ISBN 978-9188722-65-2.

Pedersen, E., Borell, J., Caltenco, H., Dahlblom, M., Gao, C., Harderup, L-E., ..., Wierzbicka, A. (2018). People as part of the energy system in residential buildings - challenges in transdisciplinary research for integrated understanding of technical installations, building performance, and tenants' perception and behavior. The 9th International Cold Climate HVAC Conference.

Stenberg, J., \& Fryk, L. (2015). Learning Lab Hammarkullen: Codesigning Renovation. Poster. OIKONET Second International Conference "Global Dwelling", 24-25 September 2015, Bratislava.

Thune, T., \& Gulbrandsen, M. J. (2014). Dynamics of collaboration in university-industry partnerships: do initial conditions explain development patterns? Technology Transfer, 39, 977. https://doi.org/10.1007/s10961-014-9331-5

Tupenaite, L., Kazimieras, E., Zavadskas, E. K., Turskis, Z., \& Seniut, M. (2010). Multiple criteria assessment of alternatives for built and human environment renovation. Journal of Civil Engineering and Management, 16(2), 257-266. https://doi.org/10.3846/jcem.2010.30

Villani, E., Rasmussen, E., \& Grimaldi. R. (2017). How intermediary organizations facilitates university-industry technology transfer: A proximity approach. Technology Forecasting \& Social Change, 114, 86-102. https://doi.org/10.1016/j.techfore.2016.06.004

Wiek, A., Ness, B., Brand, F. S., Schweizer-Ries, P., \& Farioli, F. (2012). From complex systems analysis to transformational change: a comparative appraisal of sustainability science projects. Sustainable Science, 7(Suppl), 5-24. https://doi.org/10.1007/s11625-011-0148-y

\section{Appendix A}

\section{Network of partners}

The SIRen research environment consists of researchers from ten academic institutions (Lund University, Chalmers University of Technology, KTH Royal Institute of Technology, Luleå University of Technology, RISE Research Institutes of Sweden, RISE CBI Cement and Concrete institute, Umeå University, Dalarna University, Uppsala University, and Malmö University). Most of the researchers belong to the fields of engineering and 
architecture, but some come from real-estate management and the social sciences that relate to construction. In addition, approximately thirty companies and organisations have joined the initiative: Five municipal housing owners (Framtiden - consisting of Familjebostäder, Poseidon, Bostadsbolaget, and Gårdstensbostäder, Förbo and Stockholmshem); three large nationally and internationally active contractors (Skanska, NCC, and PEAB); two large technical consultancies; one large and one small architectural company; one built environment consultancy; one renovation consultancy; one post-war housing stock renovation consultancy; one small design consultancy; three suppliers - one of solutions for façades, one of ventilation systems, and one of bath and kitchen renovation concepts. Sector organisations: the Swedish Client Construction Forum, the Development Fund of the Swedish Construction Industry (SBUF), the Sector Organisation for Ventilation and Plumbing Companies, and the Swedish Union of Tenants. Municipal agencies: City of Malmö, Skåne Energy Agency, Museum of Gothenburg, the 'Västarvet' ('West Heritage') administration (Region Västra Götaland), and the Swedish National Board of Housing, Building and Planning.

\section{Appendix B}

\section{Questions in the digital survey}

1) SIRen has given me the opportunity to conduct research that otherwise would not have been possible.

2) SIRen has given me the opportunity to carry out research in (for me) new research areas.

3) SIRen has given me the opportunity for increased research output.

4) SIRen has given me the opportunity to participate in collaborations that otherwise would not have happened.

5) In what ways has SIRen benefited your research work?

6) SIRen has given me access to a larger network of researchers.

7) SIRen has given me access to a larger business network.

8) SIRen has given me access to a larger network of municipalities and authorities.

9) In what ways has SIRen developed your network?

10) I think the SIRen conferences held twice a year are valuable.

11) In what ways do you find the SIRen conferences as valuable? Alternatively, why do you feel that they are not?

12) Who have been your main contacts during SIRen? State one or more from the following list: Your own university, other university, business, government, other (please clarify).

13) Describe what collaborations you have undertaken during the SIRen project.

Questions 1-4, 6-8, and 10 were multiple choice (strongly agree, agree, do not agree, and do not agree at all) and

Question 12 was asked to indicate which category of actors the respondents had the most contact with. For

Questions 5, 9, 11, and 13, the respondents were given the opportunity to reply in their own words.

\section{Copyrights}

Copyright for this article is retained by the author, with first publication rights granted to the journal.

This is an open-access article distributed under the terms and conditions of the Creative Commons Attribution license (http://creativecommons.org/licenses/by/4.0/). 